DOI https://doi.org/10.30525/978-9934-26-040-7-25

\title{
ПРАВОВИЙ СТАТУС СТОРІН (УЧАСНИКІВ) У СПРАВІ ПРО БАНКРУТСТВО ТА НЕПЛАТОСПРОМОЖНІСТЬ
}

\author{
Плигач Т. О. \\ acniрант \\ Університету державної фіскальної служби України \\ м. Ірпінь, Київська область, Украӥна
}

Прийняття Кодексу України з процедур банкрутства (далі - Кодекс, КУзПБ) [1] є знаковим для сфери банкрутства. Адже, необхідність реформування правовідносин у сфері банкрутства $\epsilon$ не меншою, ніж у інших сферах правовідносин.

Адже, Кодекс більш детально врегулював правове положення кожного із учасників судових процедур банкрутства, а також відносин, між різними учасниками таких процедур і їх взаємодію. Особлива увага приділена сторонам судових процедур банкрутства, оскільки без цих учасників, неможливе провадження у справах про банкрутство.

Як свідчить судова практика України, існують випадки, коли норми визначені Кодексом, які стосуються прав та обов'язків учасників справи про банкрутство, трактуються по-різному. Тому на даний час, виникають питання, що стосуються притягнення до відповідальності учасників справи за невиконання своїх обов'язків та зловживання своїми правами для задоволення власних інтересів.

Як зазначає I. Бутирська, кожен учасник провадження у справі про банкрутство має специфічний, притаманний тільки йому, правовий статус, характеристика якого зумовлена особливостями відносин неспроможності [2, с. 91].

Відповідно до ст. 1 КУзПБ [1], учасники у справі про банкрутство сторони, арбітражний керуючий, державний орган 3 питань банкрутства, Фонд державного майна України, представник органу місцевого самоврядування, представник працівників боржника, уповноважена особа засновників (учасників, акціонерів) боржника, а також у випадках, передбачених цим Кодексом, інші учасники справи про банкрутство, щодо прав або обов'язків яких існує спір.

Зокрема, розглядаючи процедуру банкрутства, доречно виділити основні сторони по справі, а саме: боржника та кредитора. 
Так, ст. 1 Кодексу України з процедур банкрутства [1] визначає, що боржник - це юридична особа або фізична особа, у тому числі фізична особа - підприємець, неспроможна виконати свої грошові зобов'язання, строк виконання яких настав. Кодекс не передбачає, що банкрутство можливе лише для тих юридичних та фізичних осіб, що здійснюють підприємницьку діяльність (суб'єктів підприємництва). Водночас, згідно з ст. 2 Кодексу законодавство про відновлення платоспроможності боржника, або визнання його банкрутом не поширюється на банки та не застосовуються до юридичних осіб - казенних підприємств [1].

Якщо, для кредитора звернення до суду із заявою про банкрутство це право, то для боржника-юридичної особи - обов'язок. Боржник зобов'язаний протягом місяця звернутися до суду із заявою про відкриття провадження у справі, у разі якщо задоволення вимог одного або кількох кредиторів призведе до неможливості виконання грошових зобов'язань боржника в повному обсязі перед іншими кредиторами (загроза неплатоспроможності), та в інших випадках, що їх передбачає Кодекс [1]. У разі допущення керівником боржника порушення цих вимог, він несе солідарну відповідальність за незадоволення вимог кредиторів. Щодо фізичної особи (фізичної особи - підприємця) у статусі боржника мають ряд особливостей. Провадження у справі про банкрутство фізичної особи може бути відкрито лише за ії власною заявою, та за наявності підстав передбачені ч. 2 ст. 115 КУзПБ [1].

Отже, порушити провадження у справі про банкрутство щодо фізичної особи складніше, ніж щодо юридичної особи.

Відповідно, у ст. 1 Кодексу, кредитор - юридична або фізична особа, а також контролюючий орган, уповноважений відповідно до Податкового кодексу України здійснювати заходи, щодо забезпечення погашення податкового боргу та недоїмки зі сплати єдиного внеску на загальнообов'язкове державне соціальне страхування у межах своїх повноважень та інші державні органи, які мають вимоги щодо грошових зобов'язань до боржника;

забезпечені кредитори - кредитори, вимоги яких до боржника або іншої особи забезпечені заставою майна боржника; конкурсні кредитори - кредитори за вимогами до боржника, що виникли до відкриття провадження у справі про банкрутство і виконання яких не забезпечено заставою майна боржника; поточні кредитори - кредитори за вимогами до боржника, що виникли після відкриття провадження у справі про банкрутство [1].

Також, Кодекс України з процедур банкрутства, закріпив ряд змін щодо прав та можливостей кредиторів. Відтепер кредитор, що не встиг податися у встановлений законом строк, потрапляє в ту ж чергу, в яку 
він мав би потрапити у разі вчасного подання заяви, однак у такому випадку цей кредитор залишиться без права голосу на зборах кредиторів [1].

Відтак, забезпеченим кредиторам надано можливість звернення стягнення на майно боржника після спливу 170 календарних днів мораторію, якщо господарським судом протягом цього часу не було винесено постанову про визнання боржника банкрутом або ухвалу про введення процедури санації. Забезпечений кредитор має право відмовитися від частини забезпечених вимог і бути одночасно і забезпеченим кредитором, і конкурсним, що надає можливість більшою мірою задовольнити свої вимоги. Також, він має право викупити предмет забезпечення після повторного і другого повторного аукціону у разі його не продажу [1]. Водночас, як і раніше, відсутність таких положень слугувала зловживанням з боку пов'язаних з боржником кредиторів.

Таким чином, Кодекс значно вдосконалив правовий статус кредитора в процедурі банкрутства, надавши нові можливості забезпеченим кредитором у межах процедури банкрутства.

Варто погодитись із В.В. Радзивілюк, яка досліджуючи фактори, що впливають на правосуб'єктність основних учасників правовідносин запобігання банкрутству (неспроможності), виділяє серед цих факторів наявність в учасників сукупності різноманітних за своєю спрямованістю та багаточисельних інтересів, не тільки спільних, але й головне протилежних [3, с. 64]. Вступаючи у справу про банкрутство, практично кожен суб'єкт прагне максимально захистити власні інтереси, що зумовлює високу конфліктогенність відносин неспроможності. Кожен з кредиторів прагне отримати максимально можливе задоволення своїх вимог до боржника.

Зіткнення інтересів кредиторів, боржника, соціальних та державних інтересів, як зазначає Н.В. Асєєва, породжує значні труднощі у правовому регулюванні правового інституту неспроможності (банкрутства). Мета застосування процедури неспроможності - це знаходження балансу між інтересами кредитора, боржника, суспільства та держави шляхом застосування до боржника різноманітних передбачених законом процедур [4, с. 13].

Отже, із зазначеного вище можна зробити висновок, що законодавець більш схильний до захисту інтересів кредиторів та притягнення до відповідальності боржника, однак все ж таки необхідно дотримуватися паритету інтересів. Отож, надзвичайно важливою $є$ роль господарських судів, оскільки саме вони формуватимуть практику та підходи до ініціювання справи про банкрутство та будуть зобов'язані запобігати будь-яким зловживанням зі сторони боржника чи кредитора. 108 


\title{
Література:
}

1. Кодекс України з процедур банкрутства: Закон України від 18.10.2018 p. № 2597-VIII. URL: https://www.zakon.rada.gov.ua/laws/ show/2597-19 (дата звернення: 02.02.2021).

2. Бутирська I. Правовий статус учасників провадження у справі про банкрутства. Підприємництво, господарство і право. 2016. № 12. С. 89-94.

3. Радзивілюк В. В. Запобігання банкрутству (неспроможності): господарсько-правовий аспект : монографія. Ніжин : ТОВ «Видавництво «Аспект-Поліграф», 2013. 532 с.

4. Асеева Н. В. Обеспечение частных и публичных интересов при банкротстве предприятия : монография. Донец. ун-т экономики и права. Донецк : ДонУЭП, 2013. 200 с.

DOI https://doi.org/10.30525/978-9934-26-040-7-26

\section{ЩОДО ОРГАНІЗАЦІЇ ПРОДАЖУ МАЙНА БАНКРУТА}

\author{
Тюріна Ю. Є. \\ адвокат \\ АО «ПРАВОВИЙ ЦЕНТР ХХІ СТ.» \\ м. Київ, Украӥна
}

Продаж майна банкрута $\epsilon$ чи не найважливішим етапом у всій процедурі банкрутства. Безпосередньо продажу майна передує низка організаційних заходів і процедур, які передбачені законодавчо. При цьому, з прийняттям Кодексу України з процедур банкрутства майно банкрута може бути продано виключно шляхом проведення електронних торгів. У зв'язку із цим організація продажу майна банкрута перетерпіла істотних змін. Дотримання умов організації та проведення продажу майна наразі $\epsilon$ запорукою вдосконалення правового інституту банкрутства.

Організація продажу майна банкрута регламентована положеннями Кодексу України з процедур банкрутства (далі - Кодекс) та Порядком організації та проведення аукціонів з продажу майна боржників у справах про банкрутство, затвердженим постановою Кабінету Міністрів України від 2 жовтня 2019 року № 865 (далі - Постанова). 